\title{
CARACTERÍSTICAS DE LOS DISTRITOS FINANCIEROS EN EL ESPACIO URBANO
}

\author{
Carlos Pérez Mejías \\ Licenciado en Geografía. Universidad de Alicante (España) \\ Correo electrónico: allstrategy@ hotmail.com
}

Recibido: 28 de noviembre de 2011. Devuelto para revisión: 16 de diciembre de 2011.

Aceptado: 16 de enero de 2012

\section{RESUMEN}

La economía es uno de los factores explicativos más importantes para entender nuestro mundo actual. Asimismo está íntimamente relacionado con la sociedad y la política, y deja una impronta visible sobre el territorio organizándolo según sus lógicas. Las actividades económicas de mayor entidad se concentran en los distritos financieros tomando unas características propias que permiten clasificarlos fundamentalmente en dos modelos: norteamericano y europeo. En estos distritos se toman decisiones que pueden tener efectos sobre la economía de lugares muy lejanos, y en muchas ocasiones, este efecto puede ser devastador. Esto propicia que sean un tema controvertido, tanto por los que piensan que sustentan el sistema capitalista y son el máximo exponente del mismo, como por los que están en contra precisamente por el modelo que representan.

Palabras clave: Distrito financiero, Economía, Reorganización espacial, Sistema capitalista, Edge City.

\section{FEATURES OF THE BUSINESS DISTRICTS IN THE URBAN AREA}

\begin{abstract}
Economy is one of the most important facts to understand our world. Also it's connected with society and politics, and makes a deep footprint in territory with a selflogical order. Financial districts get together the financial activities with an own properties that classify it in two different models: American and European. In this district is being producing important decisions on the economy of so far places, and so much time these effects can be devastating. This is a controversial topic; somebody thinks that financial districts holds capitalism and is the most important exponent of it, and the other is against the model that it represents.
\end{abstract}

Key words: Financial District, Economy, Spatial Reorganization, Capitalism System, Edge City. 


\section{CARACTERÍSTICAS DOS DISTRITOS DE NEGÓCIOS NAS ÁREAS URBANAS}

\section{RESUMO}

A economia é um dos fatores mais importantes explicativo para a compreensão do nosso mundo hoje. Também é estreitamente relacionado com a sociedade ea política, e deixa uma marca visível no território organizado de acordo com sua lógica. As principais atividades econômicas estão concentradas nos distritos negócios tomando suas próprias características que permitem sua inclusão principalmente em dois modelos: americanos e europeus. Nestes distritos a tomar decisões que podem ter efeitos sobre a economia de lugares distantes, e em muitos casos, este efeito pode ser devastador. Isso faz com que são controversos, tanto para aqueles que pensam que sustentam o sistema capitalista e são a síntese do mesmo, e por aqueles que são contra o modelo justamente porque eles representam.

Palavras-chave: Área financeira, Economia, Reorganização espacial, Sistema capitalista, A borda da cidade.

\section{INTRODUCCIÓN}

"Imagina los distritos financieros de todo el mundo no llenos de rentabilidad y aves de rapiña sino rebosantes de ritmos y sonidos festivos y placenteros. Imagina reemplazar el orden social existente por una sociedad libre y ecológica fundada sobre las bases de la ayuda mutua y la cooperación voluntaria”.

(Consigna vista en una manifestación para la cancelación de la deuda de los países pobres en Londres).

El distrito financiero nace en un intento de concentrar geográficamente las actividades financieras, al igual que los gremios se agrupaban por oficios en una misma calle o barrio en la época medieval. Actualmente formados por enormes rascacielos y con el brillo que les confieren sus vistosas cristaleras y la arquitectura moderna, en esencia representan la misma idea que hace cinco siglos.

El distrito financiero (en adelante $\mathrm{CBD}^{1}$ ) puede definirse como una región de difícil delimitación que posee las siguientes características:

- Centralidad (en términos de funcionalidad).

- Altura de la edificación.

- Localización de dos usos de suelo dominantes (oficinas y grandes almacenes).

- Altos precios del suelo (tributación igualmente elevada).

- Concentración de peatones y vehículos.

\footnotetext{
${ }^{1}$ Central Business District, según sus siglas en inglés.
} 


\section{DELIMITANDO LOS CBD}

Tal y como precisa E. García Escalona (1987, p. 414), desde 1954 según R. Murphy y J. Vance los trabajos van dirigidos en primer lugar delimitar esta área, buscando los criterios para dicha delimitación:

1. Valores del suelo (W. William-Olsson, 1940) mediante los alquileres con tributos, apoyados en que el uso del suelo es determinante del valor del mismo y viceversa. Tales indicadores son problemáticos en la práctica (aunque no se cuestiona su valor) en razón de la dificultad de la obtención de los datos, y su fiabilidad al tener como base una cifra monetaria.

2. Otros criterios que plantean igualmente dificultades por la obtención y valoración de los datos, han sido:
a. Volumen del negocio de los comercios.
b. Número de personas empleadas en las oficinas, comercio y servicios.
c. Tráfico de vehículos y peatones.

3. Criterios basados en la altura de la edificación.

4. Valor de la población y número de viviendas, basado en las secciones censales, aunque se señala que esta unidad es demasiado amplia para definir un área que se caracteriza por la ausencia de población residencial, de ahí que sea más recomendable la utilización de manzanas.

5. Usos del suelo. El modelo propuesto por Murphy en 1971 establece para la definición del CBD la diversa utilización que se efectúe de los usos del suelo, aunque quizás la primera cuestión sería definir qué usos son característicos del centro. Posteriormente mediante la cartografía de los usos y la aplicación a nivel de manzana de una serie de índices (superficie en planta de cada uso, altura e intensidad) se perfila el área. Así, se plantea posteriormente la precisión de ese centro en subáreas, especialmente del corazón del centro a través de sus usos más centrales. En ambos casos, hay una elección subjetiva en la selección de los usos del suelo calificados como centrales, una vez excluidos los usos no centrales.

Por lo tanto es muy compleja la delimitación exacta de este distrito, y a menudo existe debate y controversia al respecto. En otras ocasiones su delimitación es muy fácil, incluso puede ser establecida por organismos oficiales estatales como es el caso de Singapur (Figura 1), definido por el URA ${ }^{2}$.

\footnotetext{
${ }^{2}$ Urban Redevelopment Authority, una autoridad gubernamental propia de Singapur sobre la planificación urbana y el desarrollo.
} 
Figura 1. Delimitación del CBD de Singapur.

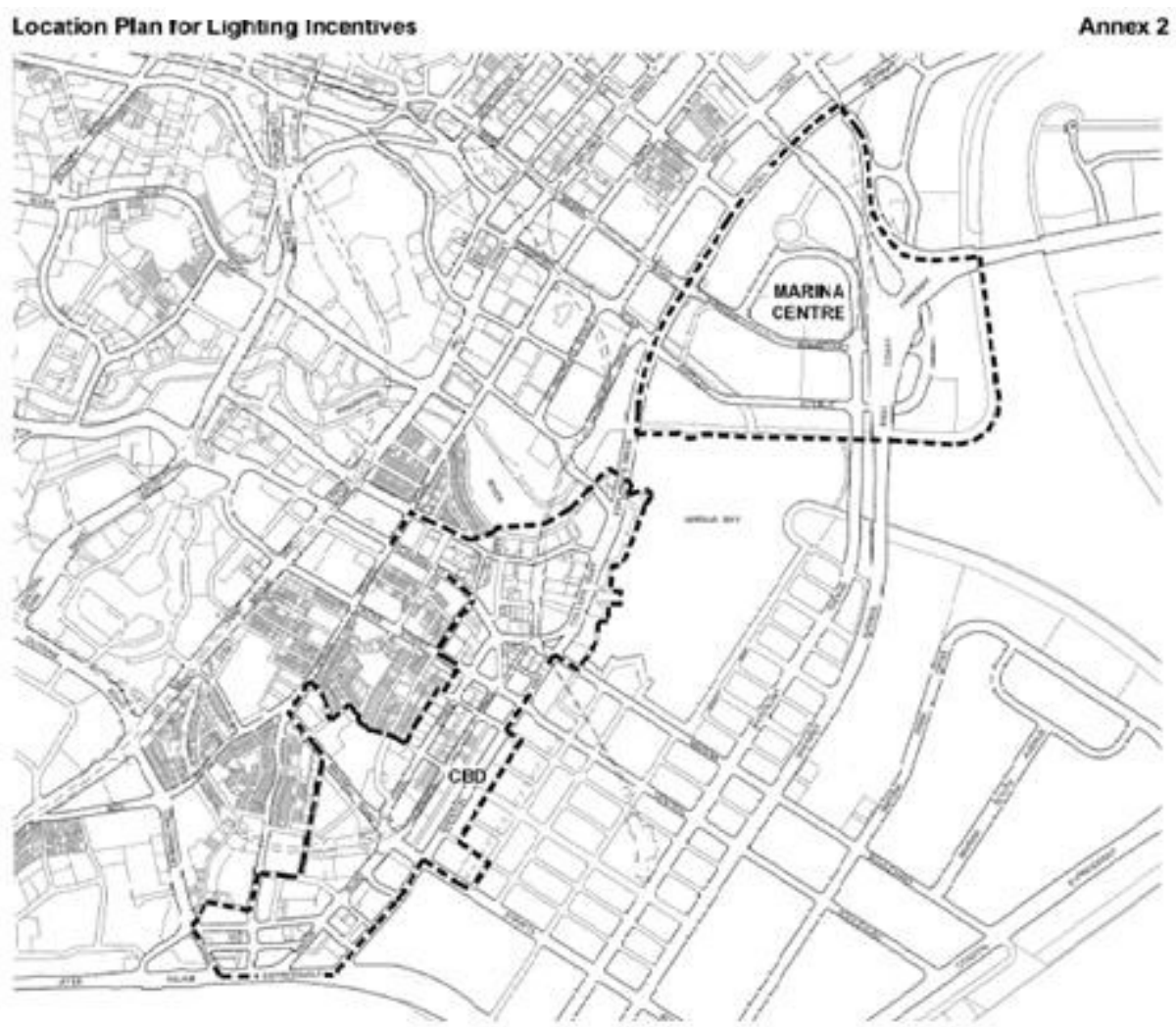

Fuente: URA.

\section{LA LÓGICA DEL CBD}

En el CBD existe una acumulación de oficinas y de comercios vinculados a unos centros direccionales $^{3}$ (Bastié y Dézert, 1980):

$\checkmark$ El centro direccional administrativo: compuesto por las sedes sociales y las administraciones.

$\checkmark$ El centro direccional comercial: conformado por grandes almacenes y venta al por mayor.

$\checkmark$ De una manera especial, el centro direccional financiero.

Existe una lógica para la localización del centro direccional, donde tendrá prioridad su ubicación en términos de toma de decisiones en lugar de depender de la proximidad a otros establecimientos. Generalmente las actividades de las sociedades de gestión están vinculadas a la concentración de la estructura financiera. El resultado es un fortalecimiento del CBD, especialmente cuando la capital política es la misma que la capital administrativa (caso de Londres y París).

\footnotetext{
${ }^{3}$ Traducción del vocablo francés "commandament".
} 
J. Bastié y B. Dézert poseen una manera muy particular de describir estos distritos:

"El CBD caracteriza a todas sus ciudades por la aparición de edificios muy funcionales, edificios de vidrio y hormigón cubierto con carteles de neón. Cada edificio muestra su nombre en luces. A veces, tiene un helipuerto encima de mismo. Sótanos que contienen hasta 6 o 7 plantas de aparcamiento reservadas para las diferentes empresas que tienen oficinas propias allí. La densidad y la altura de los edificios se zambulle en la penumbra de las calles adyacentes, y sin embargo algunas torres están coronadas con restaurantes panorámicos, o incluso piscinas y solárium.

La alta jerarquía de las empresas ocupa las plantas superiores, menos sujetas al ruido y con mejores panorámicas. El aislamiento de los edificios altos es casi perfecto: los empleados están trabajando lejos del bullicio de la calle. En algunos sótanos son los equipos de gestión los que se conectan a los terminales de ordenador que están conectados a la red. El CBD es una especie de ciudad dentro de la ciudad".

Sin duda destacan los aspectos que más llaman la atención del CBD, ya que no se trata únicamente de la altura de los edificios sino de su aspecto singular con cristaleras, luces de neón, etc. Desde los rascacielos se observa una vista privilegiada de la ciudad toda vez que logran tener un perfecto aislamiento respecto al ruido y bullicio de la misma, a pesar de estar situados en el corazón de la ciudad.

A Bastié y Dezért les sorprende la gran disponibilidad de plantas de aparcamiento ubicadas en los sótanos de los edificios. De esta manera se puede paliar una de las desventajas de esta céntrica ubicación (falta de espacio para vehículos) ya que las ventajas que posee son obvias, sin embargo puedo afirmar que ésta es actualmente una característica que ha perdido vigencia. El gran número de oficinas, sedes sociales o grandes almacenes que se ubican en el distrito y la gran cantidad de personal que trabaja allí hacen prácticamente imposible que se pueda estacionar el vehículo propio, con lo cual los desplazamientos mayoritariamente se efectúan en transporte público (autobús o metro) o en taxi.

Otro detalle que no se debe escapar es el hincapié que estos autores inciden en la jerarquía de distribución del espacio en la vertical: así, las de una posición jerárquica más alta se ubicarán en los pisos superiores lo cual les sitúa a mayor distancia de la calle, mientras que los equipos de gestión no necesitan una ubicación específica, es más, pueden situarse en sótanos o como ya precisaron A. Moreno y S. Escolano, incluso pueden descentralizarse fuera del CBD ya que gracias a las TICs trabajarán conectados a internet sin necesidad de esa cercanía espacial de la que precisaban anteriormente.

En ocasiones, el CBD da lugar al atrio o atrium ${ }^{\mathbf{4}}$, un espacio de carácter semipúblico situado en la planta baja, al estilo de una plaza tradicional, pero surge precisamente por la escasez de las mismas.

\footnotetext{
${ }^{4}$ A similitud de los atrios ubicados en las casas romanas de las clases altas, los Domus.
} 
Es un espacio que acaba siendo cedido al ciudadano, de una manera diferente al antiguo espacio público. Es el caso de la Potsdamer Platz ${ }^{5}$ de Berlín (Fotografía 1).

\section{Fotografía 1. Potsdammer Platz, Berlín.}

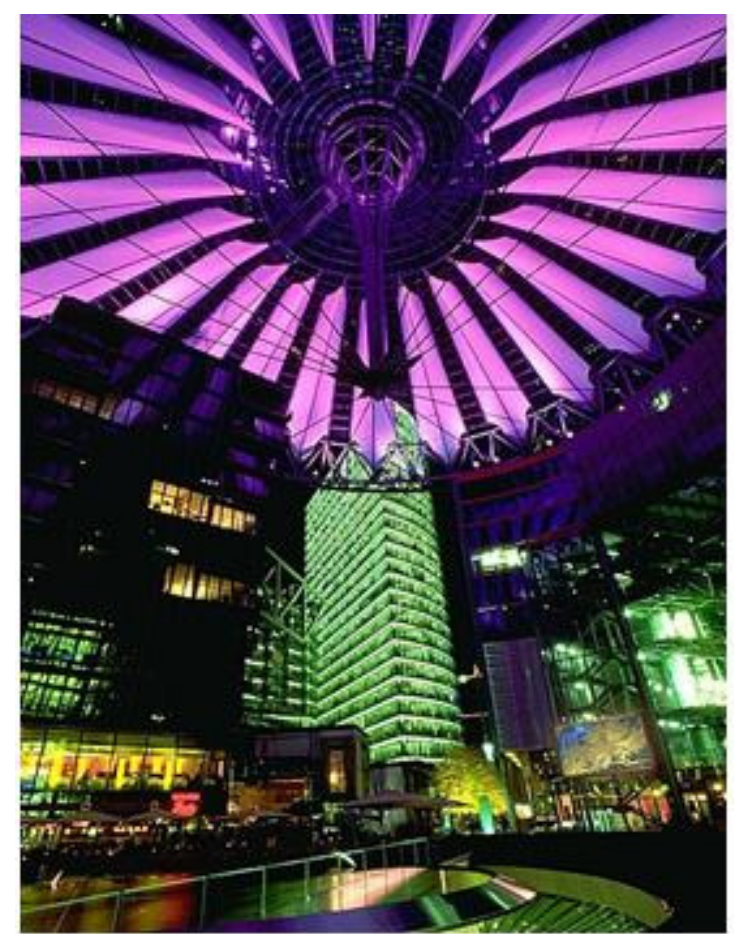

Fuente: Google imágenes.

\section{CBD NORTEAMERICANO VS CCN ${ }^{6}$ EUROPEO}

Tal y como afirman J. Bastié y B. Dézert, el CBD durante mucho tiempo fue un fenómeno norteamericano, aunque posteriormente surgió en Europa en los casos de Londres y Paris. El CBD norteamericano fue el resultado de una situación específica que se concentró en un determinado punto, el cual fue Manhattan. Los intercambios comerciales en el s. XIX favorecieron la creación de nuevos capitales políticos y financieros: la ampliación de las transacciones de las bolsas de valores y la creación de negocios y oficinas diferenció esta parte de la ciudad de las demás. Esto se debió a la voluntad de los líderes financieros e industriales para maximizar una ubicación favorable situada en un estuario, con zona portuaria y un gran nudo ferroviario, todo ello en un espacio reducido de máximo valor.

\footnotetext{
${ }^{5}$ La Potsdammer Platz fue muy dañada durante la II Guerra Mundial mientras que en la guerra fría estaba atravesada por el Muro de Berlín, con lo cual el lugar permanecía desierto. Posteriormente se ha convertido en uno de los símbolos de la reunificación alemana y a través de la arquitectura moderna, donde destaca el edificio del Sony Center, ha tomado el aspecto que conocemos hoy día. Allí se celebra el festival de Cine de Berlín - Berlinale-.

${ }^{6}$ Centro Comercial y de Negocios, debido a las funciones que aglutina.
} 
Sin embargo desde el final de la II Guerra Mundial la reestructuración de los centros de las ciudades en Europa y Japón llevó a imitar a los CBD de América del Norte. Así se ubica a menudo un distrito de negocios adyacente al centro histórico. Para satisfacer las necesidades de metros cuadrados de oficinas, se decidió suprimir la prohibición de alturas en los edificios en Londres en 1963 y en París desde 1965. Así, comenzaron a imponerse los rascacielos con la construcción del National Westminster Bank (Londres) de 52 pisos, situado en el distrito del mismo nombre, agrupando un CBD que comprende oficinas y departamentos de grandes empresas. En París, en el distrito de los campos Elíseos que se extienden por la avenida de Neuilly (alejándose por lo tanto del centro tradicional) durante el período de continuo crecimiento hasta 1974, se vendieron más oficinas que apartamentos.

A diferencia de otros países, el modelo francés de CBD se situó en antiguas instalaciones militares conformándose una zona burguesa en el centro, gracias a lo cual surgió un comercio difuso que enseguida se identificó con el parcial uso residencial.

Por contra, la evolución en América del Norte del CBD distinguió 6 características esenciales:

La proliferación de oficinas, el rápido crecimiento del precio del suelo, y la expansión en forma de rascacielos.

$>$ Un reequilibrio del comercio específico y renovado a expensas del comercio tradicional.

$>$ Un aumento del consumo y entretenimiento (teatros, cines, clubes nocturnos).

> Una regresión en la ocupación de lugares centrales de la venta al por mayor, ubicándose en la periferia.

$>$ Desarrollo de los edificios administrativos de ente regional, lugares para efectuar reuniones, conferencias y congresos.

$>$ La residencia quedó menos representada en estas ubicaciones centrales.

Pese a que toda la isla de Manhattan tiene una actividad frenética y puede poseer algunas de las características que definirían al CBD, sólo se toma como tal el distrito situado en la parte más meridional de la isla, coincide por lo tanto con la zona de mayor densidad de rascacielos ${ }^{7}$ (Figura 2).

\footnotetext{
${ }^{7}$ Los rascacielos se concentran preferentemente en el Downtown seguido por el Midtown en la zona de Times Square.
} 
Figura 2. CBD de Nueva York.

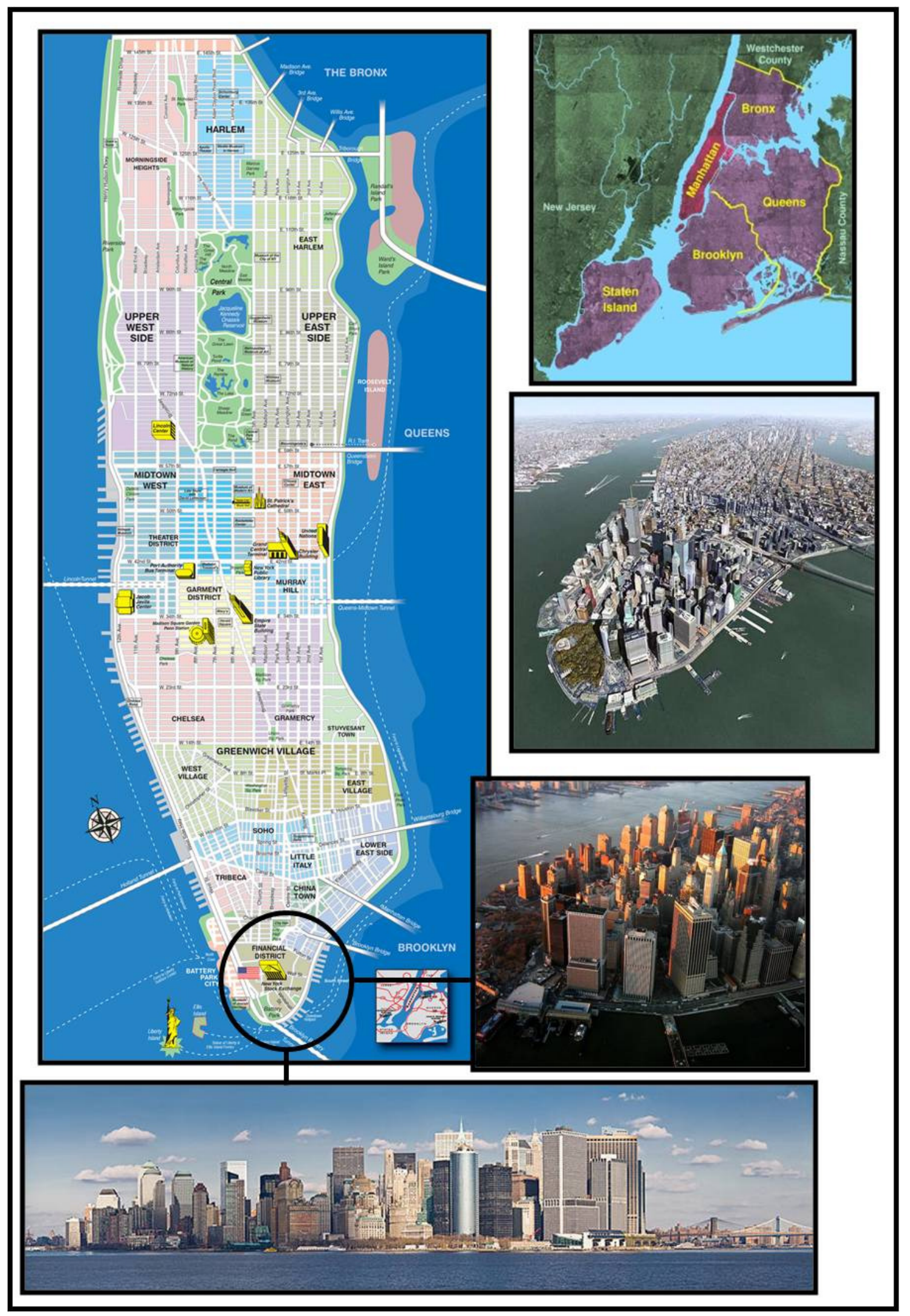

Fuente: Google imágenes. Elaboración propia. 
En este sector ${ }^{8}$ formado por numerosos rascacielos empresariales destaca entre otros el edificio de Wall Street. Históricamente esta zona ya tenía mucha importancia, no en vano fue aquí donde George Washington ubicó el primer Capitolio de EE.UU. Posee un uso mayoritariamente empresarial aunque se está incrementando muy poco a poco el número de hoteles, y en menor medida, de apartamentos. Aquí se ubicaba el World Trade Center ${ }^{9}$ (actualmente Zona Cero) un complejo de oficinas formado por dos torres gemelas de 110 plantas cada una, ubicado en el corazón del distrito financiero de Nueva York y célebre por los atentados ocurridos el 11 de Septiembre de 2001.

\section{Fotografía 2. Vista aérea de Manhattan.}

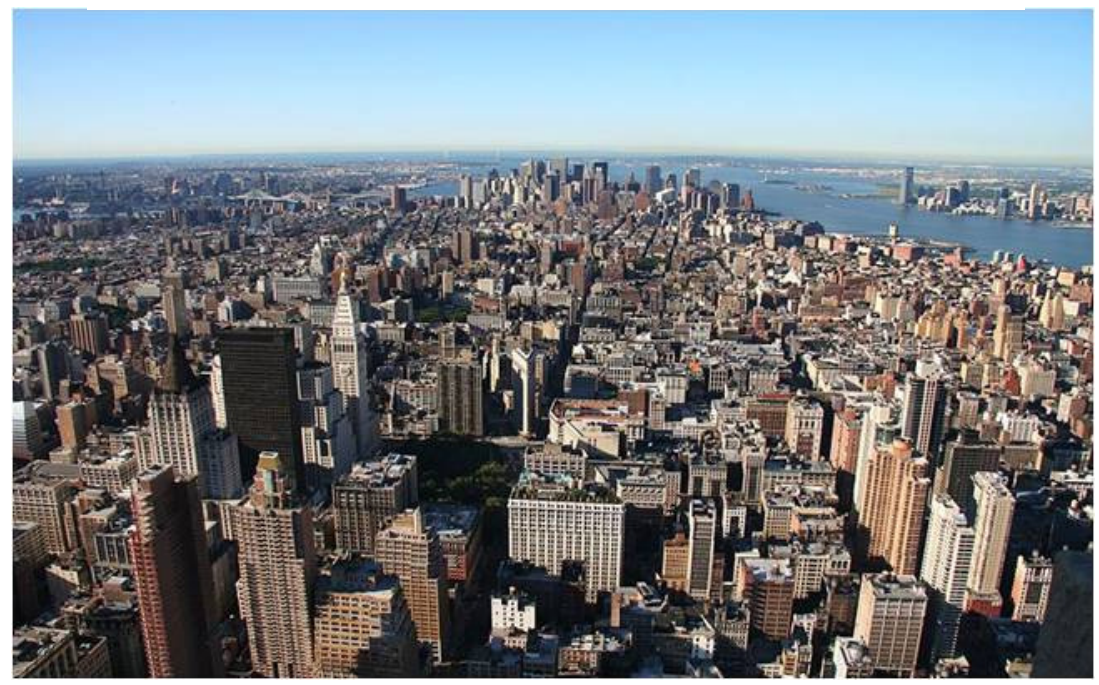

Fuente: Google imágenes.

Durante el día ofrece una actividad muy frenética, a diferencia de la noche donde apenas se registra movimiento ya que los edificios de administración y oficinas permanecen cerrados. Aquí se ubican igualmente muchos atractivos turísticos como la Estatua de la Libertad, el monumento a George Washington o la ya mencionada Zona Cero $^{10}$. También destaca por su vistosidad y tamaño, el puente de Brooklyn. Es el CBD propiamente dicho.

Por su parte, en el Midtown se encuentran la mayor parte de los rascacielos correspondientes a hoteles y apartamentos. Más de 700.000 personas trabajan en sus oficinas, hoteles y establecimientos, ya que existen numerosísimas tiendas, especialmente en Times Square y en la $5^{\circ}$ Avenida. Aquí se ubica Broadway, epicentro del teatro, la Catedral de San Patricio, el cine más grande del mundo (hasta 6.000 personas de aforo) o el edificio Rockefeller Center. También destaca la New York Public Library, la sede de Naciones Unidas, el Empire State y el Madison Square Garden, estadio de los New York Knicks.

\footnotetext{
${ }^{8}$ También se le conoce como Downtown o Lower Manhattan.

${ }^{9}$ Centro del Comercio Mundial o WTC según sus siglas en inglés.

${ }^{10}$ Tras los atentados del 11 de Septiembre se ha convertido en uno de los lugares más visitados por los turistas, unos 9 millones al año, según muestran las estadísticas tras el décimo aniversario del atentado. Ello se ha visto reflejado en la cantidad de hoteles en su entorno, que ha pasado de 6 con un total de 2.300 habitaciones antes de 2001 a 18 en 2011 con más de 4.000 habitaciones.
} 
El WTC no estaba compuesto únicamente por las torres gemelas sino que era un complejo de 7 edificios (Figura 3) los cuales se describen a continuación:

- Torres gemelas (oficinas):

- Torre norte (WTC 1) en las plantas 106 y 107 había un restaurante llamado "Windows on the World" y en la azotea había una antena de telecomunicaciones.

- Torre sur (WTC 2) tenía un puesto de observación en el piso 107, conocido como "Top of the World Trade Center Observatories".

- Hotel Marriott (WTC 3) con una calificación de 4 diamantes, superior a 5 estrellas. Quedó destruido debido al derrumbe de las dos torres.

- WTC 4, edificio de oficinas de 9 plantas. Aquí tenía su sede el Deutsche Bank.

- WTC 5, edificio de oficinas de 9 plantas, con forma de L. Aquí había oficinas de US Airways y American Airlines, entre otras.

- WTC 6, edificio del gobierno de 7 plantas que albergaba la Aduana de los EEUU.

- WTC 7, edificio de 186 metros de altura y 47 plantas. En él estaban ubicados 7 órganos o comisiones del gobierno.

Figura 3. Plano del WTC.

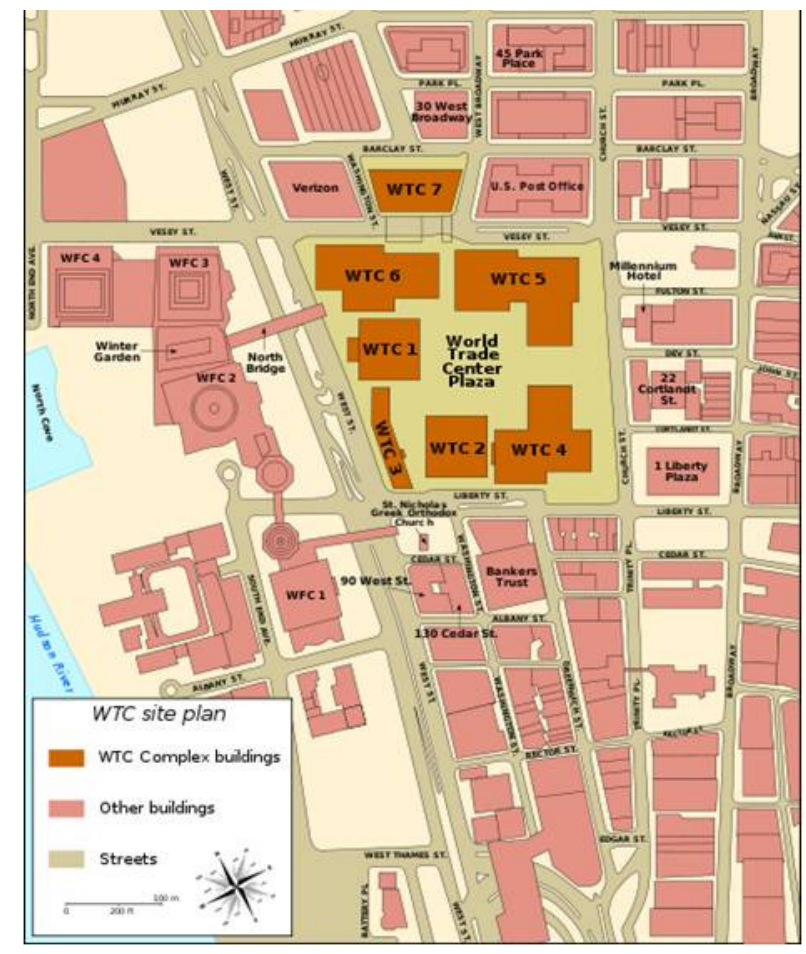

Fuente: Google imágenes.

Por lo tanto en el WTC se localizaban servicios terciarios de lujo, sedes de bancos, aerolíneas y oficinas del gobierno. Es un ejemplo de fusión de las actividades económica y administrativa de los centros direccionales financieros y especialmente de administración que describieron J. Bastié y B. Dézert. 
Figura 4. La clave del CBD de NY, los rascacielos de oficinas.

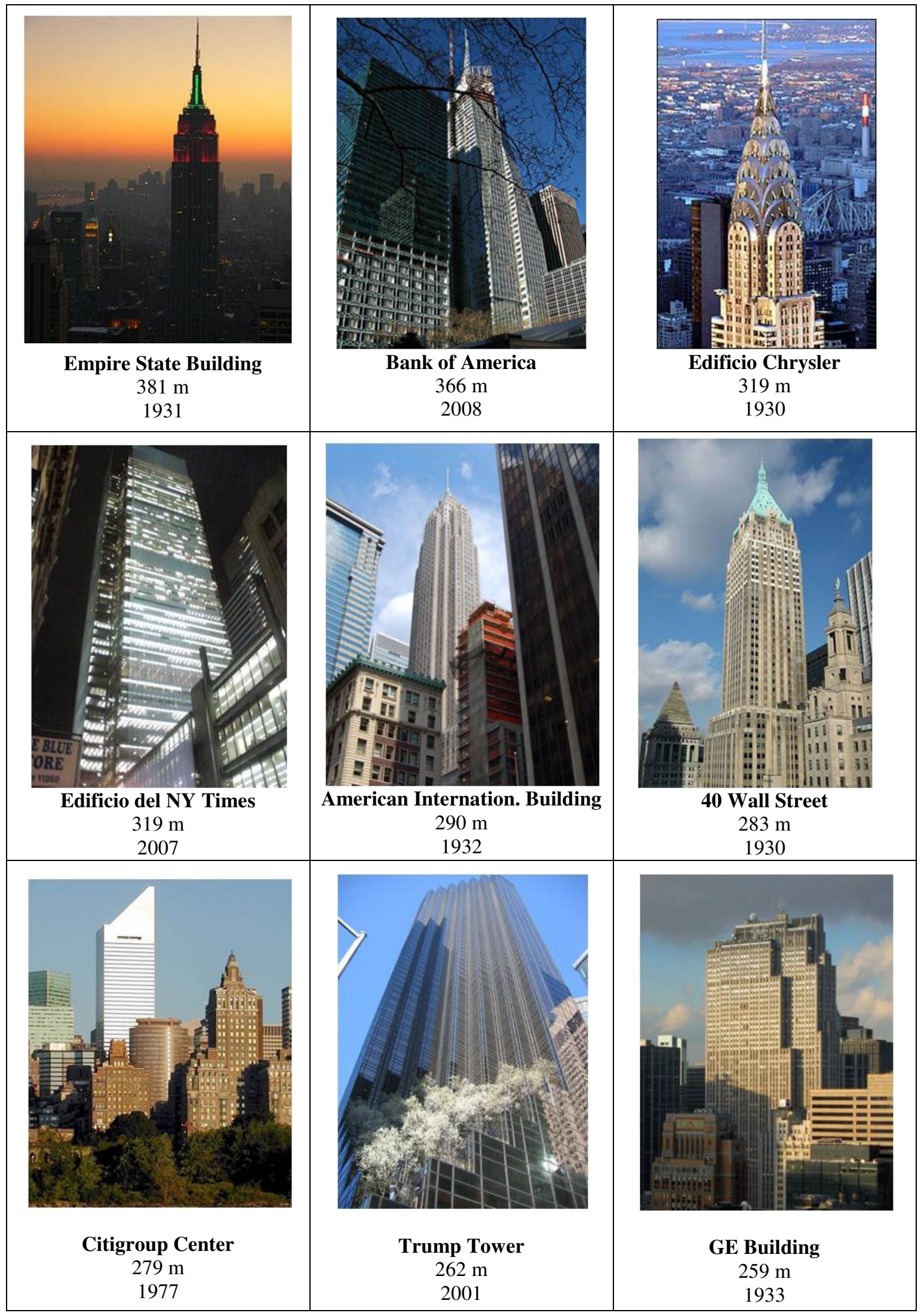

Fuente: Google imágenes. Elaboración propia. 
El hecho clave que cambió la fisionomía de Manhattan y marcaría un hito en la historia de la arquitectura fue la introducción del acero como material de construcción. Antes los materiales más utilizados eran la piedra, el ladrillo, la madera o el hierro fundido. Sin embargo para construir edificios de más de 10 pisos se necesitaban que las paredes de la base fueran muy gruesas, o la utilización de materiales de una mayor dureza. Antes de la invención del ascensor, evidentemente la limitación estriba en el número de escalones que se podían subir sin que ello supusiera un gran inconveniente.

Así, a comienzos del siglo XX las grandes ciudades empezaron a mirar en vertical para sus futuras expansiones en vez de la tradicional mirada horizontal, más aún en una isla como Manhattan donde la superficie para construir empezaba a cotizarse a precio de oro. Y que mejor manera para aprovecharla que multiplicando el espacio a lo alto. Así nació, entre incredulidad y desconfianza, el Flatiron Building, que con 87 metros de altura y una arriesgada forma supuso una revolución para su época al convertirse en el primer rascacielos de la ciudad.

A Nueva York se le conoce como "la ciudad de los rascacielos" y no es mera casualidad ya que posee medio centenar de edificios que superan los 200 metros de altura y otra centena que rebasa los $150 \mathrm{~m}$. Estos rascacielos poseen estructuras y formas muy innovadoras (Figura 4) lo cual provoca una gran vistosidad y un skyline que pasará a ser un icono característico de la ciudad, tarea a la que ha contribuido más que notablemente la historia del cine convirtiendo la ciudad en un producto turístico reconocido y deseado durante generaciones.

Estos rascacielos conforman el centro direccional administrativo y financiero, toda vez que se establecen como auténticos monumentos en su forma y diseño que atraen turistas de la misma manera que lo puede hacer la Estatua de la Libertad. Por lo tanto actúan de efecto llamada para el sector turístico, sin embargo mientras que sus calles están llenas de gente y rezuman vida durante una parte del día, se ofrecen solitarias y vacías de significado durante la otra, dada su alta especialización en actividades financieras y administrativas. Así, el protagonismo se desplaza al Midtown, donde el sector servicios, los grandes almacenes o el uso residencial son mayoritarios, y según cae el día sus calles no cesan de estar plenas de gente mientras que poco a poco los carteles de neón van iluminando sus avenidas, siendo Times Square el centro neurálgico de todo este complejo.

Por lo tanto el caracterizado como modelo norteamericano conlleva un uso mayoritario administrativo y de dirección, unido a la concentración de las actividades financieras, lo cual provoca un contraste más intenso con el resto de la ciudad. De esta manera se impide que estas zonas puedan ser aprovechadas para el disfrute de sus ciudadanos al no existir apenas plazas ni zonas verdes, donde además el uso residencial resulta mínimo.

Es de resaltar, empero, que las características del CBD norteamericano no se limitan únicamente a un área geográfica concreta, en efecto existen notables ejemplos que cumplen esas características en el otro lado del planeta donde quizás el más prototípico lo supone, entre otros, Tokio $^{11}$ (Figura 5).

\footnotetext{
${ }^{11}$ En 1945 durante el transcurso de la II Guerra Mundial el 90\% de los edificios en el área del CBD de Tokio fueron destruidos. Su aspecto actual, establecido ya en 1947, muestra una influencia norteamericana evidente.
} 
Figura 5. CBD de Tokio.

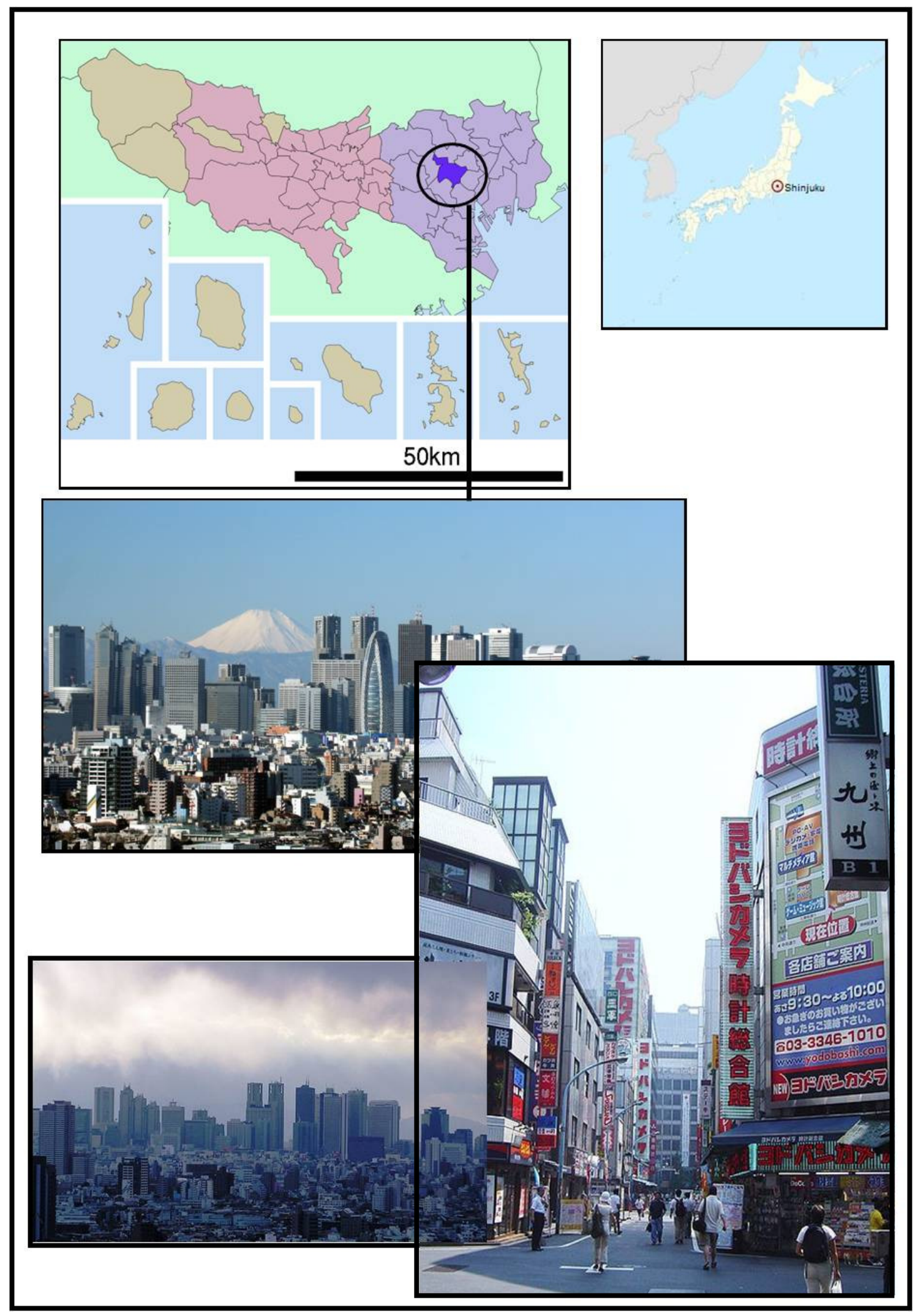

Fuente: Google imágenes. Elaboración propia. 
El CBD de Tokio lo conforma el distrito de Shinjuku, uno de los 23 Barrios Especiales de Tokio y el más importante centro comercial y administrativo de la capital. Allí se encuentra su famosa estación de trenes, siendo ésta la más utilizada del mundo (un promedio de 3 millones de personas emplean la estación diariamente) y el edificio del Gobierno Metropolitano de Tokio, el cual es el centro de la administración de la capital y símbolo urbano más importante de la parte oriental de la ciudad.

Shinjuku posee la más alta tasa de inmigrantes registrados que cualquier otro barrio en Tokio. Allí se ubican más de 107 nacionalidades diferentes, siendo los habitantes de Corea, China y Francia los más numerosos. En el área cercana de la estación se encuentra una gran concentración de tiendas de electrónica, centros comerciales, cines, restaurantes y bares, además de muchos hoteles. Concretamente las áreas que se encuentran anexas al CBD son las siguientes:

- Ichigaya, un área comercial, al este de Shinjuku. Se encuentra la Agencia de Defensa Japonesa.

- Kabukichō, un distrito conocido por sus bares y restaurantes, con tintes de barrio rojo debido a las prostitutas y otros tipos de comercio sexual.

- Nishi-shinjuku: en este distrito se encuentran la mayoría los rascacielos de Tokio (oficinas).

- Okubo: es conocido por ser un distrito con abundancia de inmigrantes coreanos.

- Shinanomachi: En la parte sureste se encuentra el Estadio Nacional (Olímpico).

- Jardín Nacional Shinjuku Gyoen: es un gran parque con 58,3 hectáreas, con 3,5 $\mathrm{km}$ de radio, donde se mezclan el estilo japonés, inglés y francés en las decoraciones de los jardines.

- Waseda: se encuentra cercana a la Universidad de Waseda, que es una de las universidades privadas más prestigiosas de Japón.

Por lo tanto a pesar de poseer una delimitación quizás más amplia que el Downtown neoyorquino con la aglutinación de bastantes comercios, en sus usos se aprecian coincidencias con el CBD de NY toda vez que sus áreas anexas resultan similares al Midtown de NY. Recordar que la delimitación no es el criterio importante en este caso, sino el hecho que el centro de negocios coincida con el centro administrativo o de mando.

\section{Fotografía 3. Vista aérea nocturna de Shinjuku.}

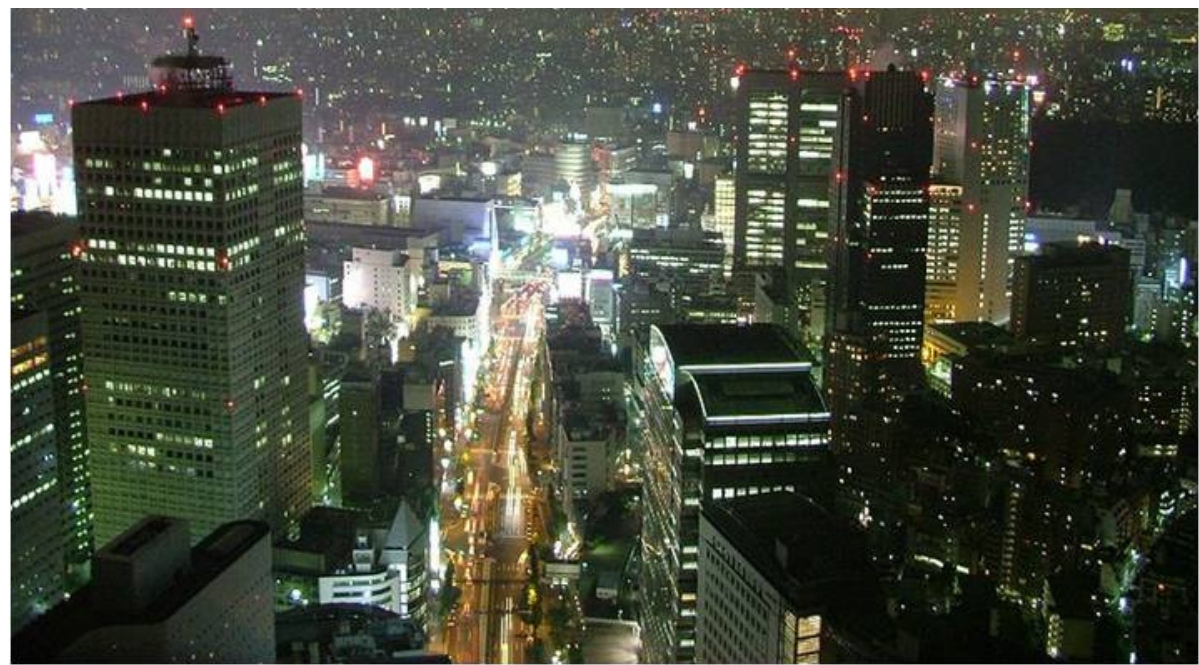

Fuente: Google imágenes. 
En Europa, por el contrario, a partir del centro histórico original el centro actual está en un proceso de reestructuración de diferentes maneras, por ejemplo la zona de la estación en París es zona de oficinas y actividades comerciales a la vez que se codea con zonas residenciales. Por lo tanto las áreas centrales todavía son bastante residenciales.

Contrariamente a Estados Unidos, la crisis de los centros históricos en Europa occidental se encuentra en fase ascendente: ciudades satélite terciarias están creciendo rápidamente, eliminando el centro tradicional de una parte importante de sus actividades. Los ejemplos más típicos se encuentran en París con el nuevo distrito de la Défense y Frankfurt con la Stadt Noroeste, un centro de servicios integrados abarcando edificos públicos del gobierno y edificios privados, con una zona para ir de compras y recreación. Y es que en Europa, durante la reconstrucción tras la devastación de la II Guerra Mundial, se tuvo gran cuidado en el mantenimiento de la complejidad de las funciones del centro de la ciudad.

Algunas ciudades han construido un segundo centro funcional a partir del núcleo tradicional posibilitando la existencia de dos centros claramente separados, por ejemplo Oxford, Turín, Milán o Estocolmo construyeron sistemáticamente su "centro de negocios".

Para obtener más eficiencia, de hecho, los centros se duplican; el centro administrativo y de mando tiende a desvincularse del centro de negocios, se pierde su supremacía absoluta en favor del establecimiento de zonas comerciales, las cuales se desarrollan cerca de los perímetros de las oficinas de negocios y de sedes sociales, que tienden a instalarse en los suburbios residenciales a veces a muchos kilómetros del centro tradicional buscando el espacio que necesitan fuera de la ciudad. Esta duplicación del centro se produce en los dos centros financieros más importantes de Europa: La Défense en Paris, y La City en Londres.

Tomando como ejemplo el caso de Londres, en su sector central conviene diferenciar La City $^{12}$ (Figura 6), esto es, el centro de negocios y CBD propiamente dicho, y Westminster, lugar de residencia de las clases más privilegiadas donde se sitúa la Abadía de Westminster (acoge las coronaciones y los matrimonios reales) y el Palacio de Westminster (allí se sitúan las dos cámaras del parlamento).

La población residencial de la City no supera los 9.000 habitantes, pero el número de personas que trabajan allí es de alrededor de 320.000. En los años 90 se comenzó con el establecimiento de hoteles y galerías comerciales en este sector. Posee los edificios más altos de la ciudad y concentra las actividades financieras de mayor importancia de la capital, permaneciendo separado del centro de mando. Posee escasos rascacielos, quizás el más llamativo es el 30 St Mary Axe, de aspecto fálico, diseñado por Norman Foster.

En suma, quedando el centro de mando y de negocios alejado del centro tradicional, las crecientes actividades comerciales pueden llevar a hablar de Centro Comercial y de Negocios (CCN) como contraposición al modelo norteamericano de CBD propiamente dicho donde únicamente destacan las actividades administrativas y de negocios.

\footnotetext{
12 Aunque en la época medieval la City constituía la extensión total de Londres, actualmente este concepto es utilizado para referirse a pequeña parte de la ciudad, coincidente con el sector más antiguo. La City y los 32 London boroughs (divisiones administrativas o circunscripciones, de rango similar al municipio) conforman el conocido como Gran Londres.
} 
Figura 6. CBD La City, Londres.

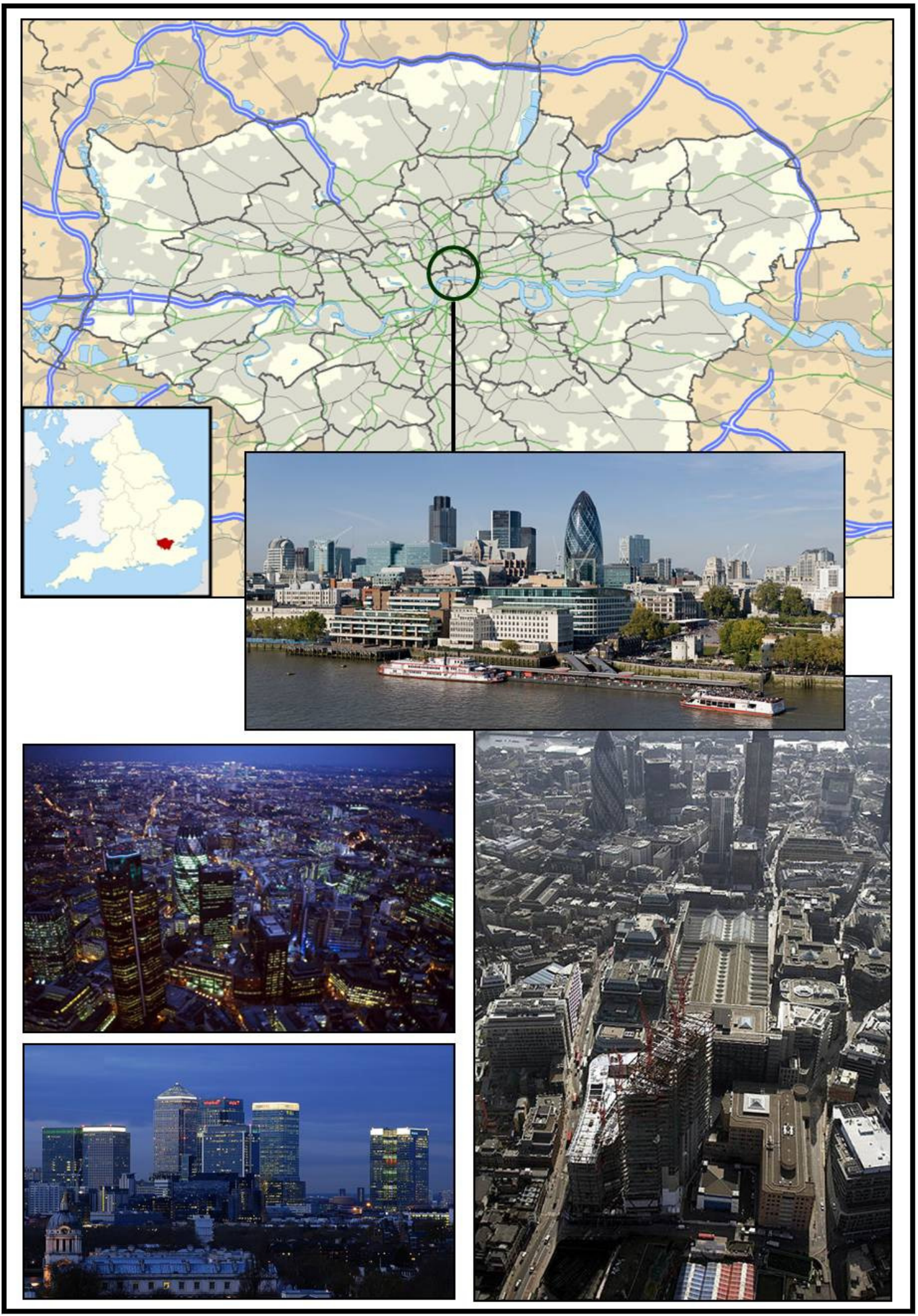

Fuente: Google imágenes. Elaboración propia. 
Como consecuencia cabe afirmar una diferencia de usos entre Westminster, la City y su área circundante (Figura 7). En la City, ubicada en el sector occidental, se concentran las actividades económicas con la Bolsa y el Banco de Inglaterra. Siguiendo el curso del Támesis en sentido oriental se ubican los comercios de lujo y restaurantes que lo comunican con Westminster, centro de mando con el Palacio de Buckingham y la Abadía de Westminster y el Palacio donde se ubica el Parlamento. En este sector hacia el oeste se ubican todas las embajadas y grandes hoteles, mientras el uso residencial está distribuido por todo el norte de ambos distritos.

Los hoteles y galerías comerciales que han florecido estos últimos lustros en La City unido al cese de la dinámica pasada de continua expulsión de población de este distrito, aseguran la diversificación huyendo de la elevada especialización en el sector económico de esta área. La existencia de monumentos en toda la zona asegura la llegada de turistas, unido a la potenciación de galerías comerciales que fija la población y propicia un mayor uso y disfrute de la calle por parte del ciudadano londinense.

Figura 7. Diferencia de usos entre Westminster y La City, Londres.

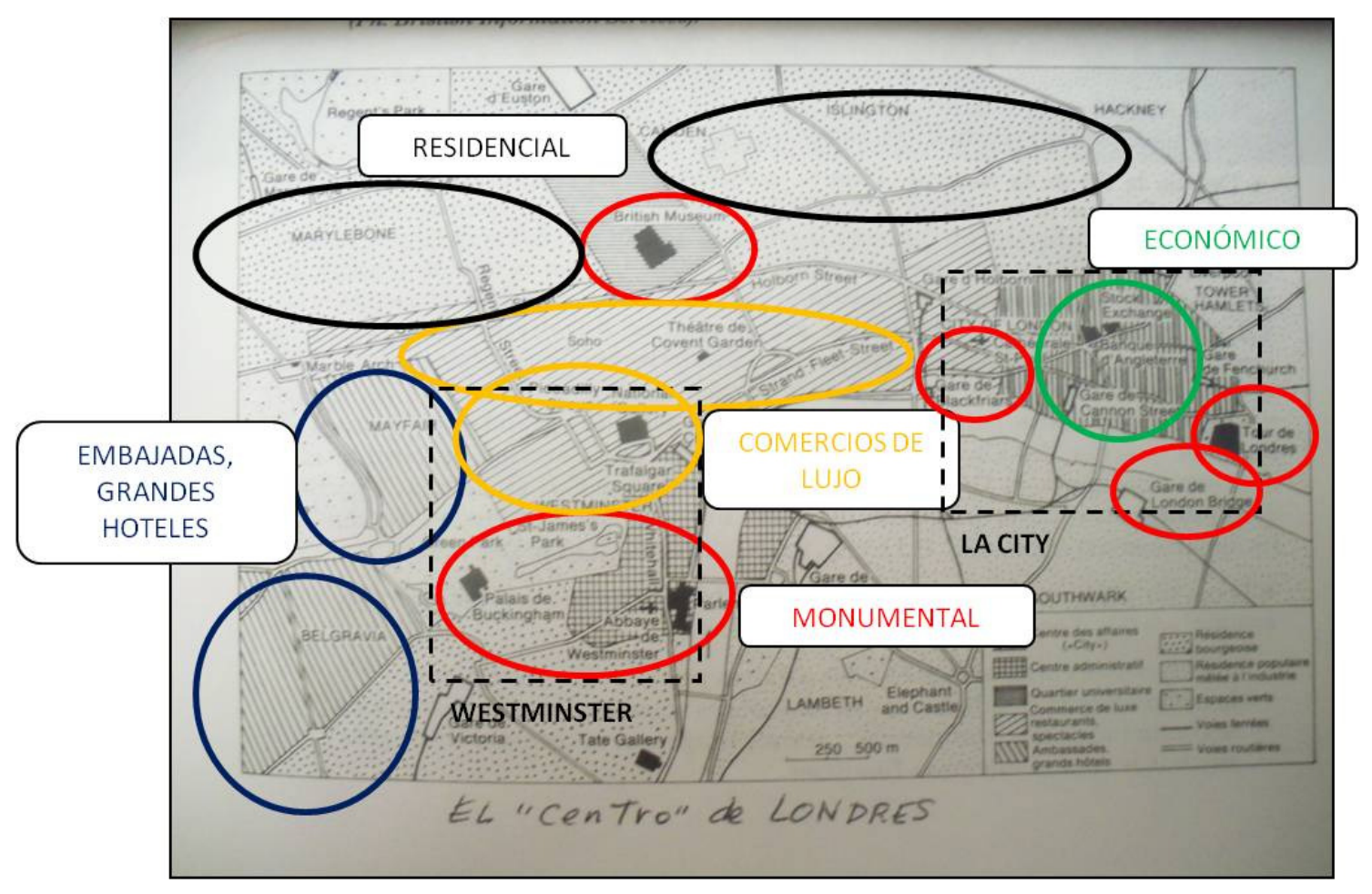

Fuente: J. Bastié y B. Dézert (1980). Elaboración propia.

Retomando la idea del proceso de reestructuración de los centros ya mencionada, Moreno y Escolano afirman que admitiendo el uso informatizado, la robotización y la utilización de las TICs como uno de los factores de mayor importancia hoy día, se puede formular la hipótesis de que existen nuevas posibilidades para la reorganización espacial de ciertas funciones de las empresas. Esto es así para las divisiones productivas, pero especialmente, para las directivas (Moreno y Escolano, 1992). 
Conviene asimismo recordar que han variado los modelos de comunicación en el interior de la empresa, las formas de relación con el exterior y por lo tanto se relocalizan todas las dependencias empresariales. El hecho crucial hoy día es la información y la comunicación, no tanto la localización.

No en vano, la transformación de los textos e imágenes en formatos digitales, la capacidad de almacenación y recuperación de los mismos y la transmisión por fibra óptica han dado como resultado estos nuevos sistemas de información que han posibilitado este desdoblamiento del centro de la ciudad (Moreno y Escolano, 1992) y ha permitido establecer las nuevas centralidades y funcionalidades en los CBD.

\section{LAS NUEVAS FUNCIONES DEL CBD}

J. Bastié y B. Dezért se refirieron a principios de la década de los años ochenta del siglo $\mathrm{XX}$ al proceso de descentralización de actividades económicas que sucedía en el centro de París. Así, la mayoría de las oficinas y los servicios hicieron que las operaciones se concentraran en un centro de negocios formado por edificios modernos, una zona donde se encuentran las oficinas de empresas de importación y exportación, oficinas de cambio, agencias de viajes y las principales compañías aéreas, donde los hombres de negocios frecuentemente viajan de un lugar a otro. Las relaciones personales son muy importantes, y se manifiestan con la instalación de clubes, centros de seminarios o de conferencias (ej. Palacio de Congresos de París).

Unido a ello gran relevancia cobró en la segunda mitad de la centuria precedente el hecho que el mercado de valores atrajera la especulación con metales preciosos, especialmente el oro, estableciendo tiendas y compradores de oro, comerciantes de diamantes, coleccionistas de arte, antigüedades y rarezas, medallas y monedas, cubriendo calles enteras en el corazón de la ciudad de Londres, el centro de Ámsterdam, Zurich, y París (barrio de la Ópera y de la Bolsa).

De esta manera el centro financiero se benefició de los efectos indirectos de las empresas de divisas relacionados con las transacciones, expertos, analistas financieros, asesores fiscales, agentes, traductores y juristas internacionales, todos ellos invadirán las actividades del CBD. No obstante la actual aglomeración existente sería el producto de varios ciclos de implantación con dos posibilidades: los comercios y los servicios se adaptan a los edificios existentes en el distrito, o bien se destruye la estructura original para crear otra que se adapte a las nuevas necesidades actuales con un estilo diferente (Bastié y Dézert, 1980).

Actualmente asistimos a una adaptación de una zona comercial, constituyendo grandes arterias radiales, con comercios de alto nivel adquisitivo. Así, la avenida Charles de Gaulle dirección Neuilly, una calle comercial, se transformó en un eje que une el tradicional distrito financiero de París y el nuevo distrito de la Défense ${ }^{13}$ (Figura 8). Se

\footnotetext{
${ }^{13}$ La Défense es un moderno distrito de negocios que surge como prolongación del eje histórico que comienza en el Louvre y prosigue por la avenida de los Campos Elíseos, el Arco de Triunfo hasta el puente de Neuilly y el Arco de la Défense. Iniciado por el Gobierno francés en 1958, el distrito alberga 3,5 millones de $\mathrm{m}^{2}$ de oficinas, haciendo de este complejo el más grande de Europa en un distrito desarrollado específicamente para empresas.
} 
han suprimido las tiendas y los negocios comunes que permanecen en los edificios antiguos están sufriendo importantes transformaciones en sus actividades y su finalidad.

Figura 8. CBD La Défense, Paris.

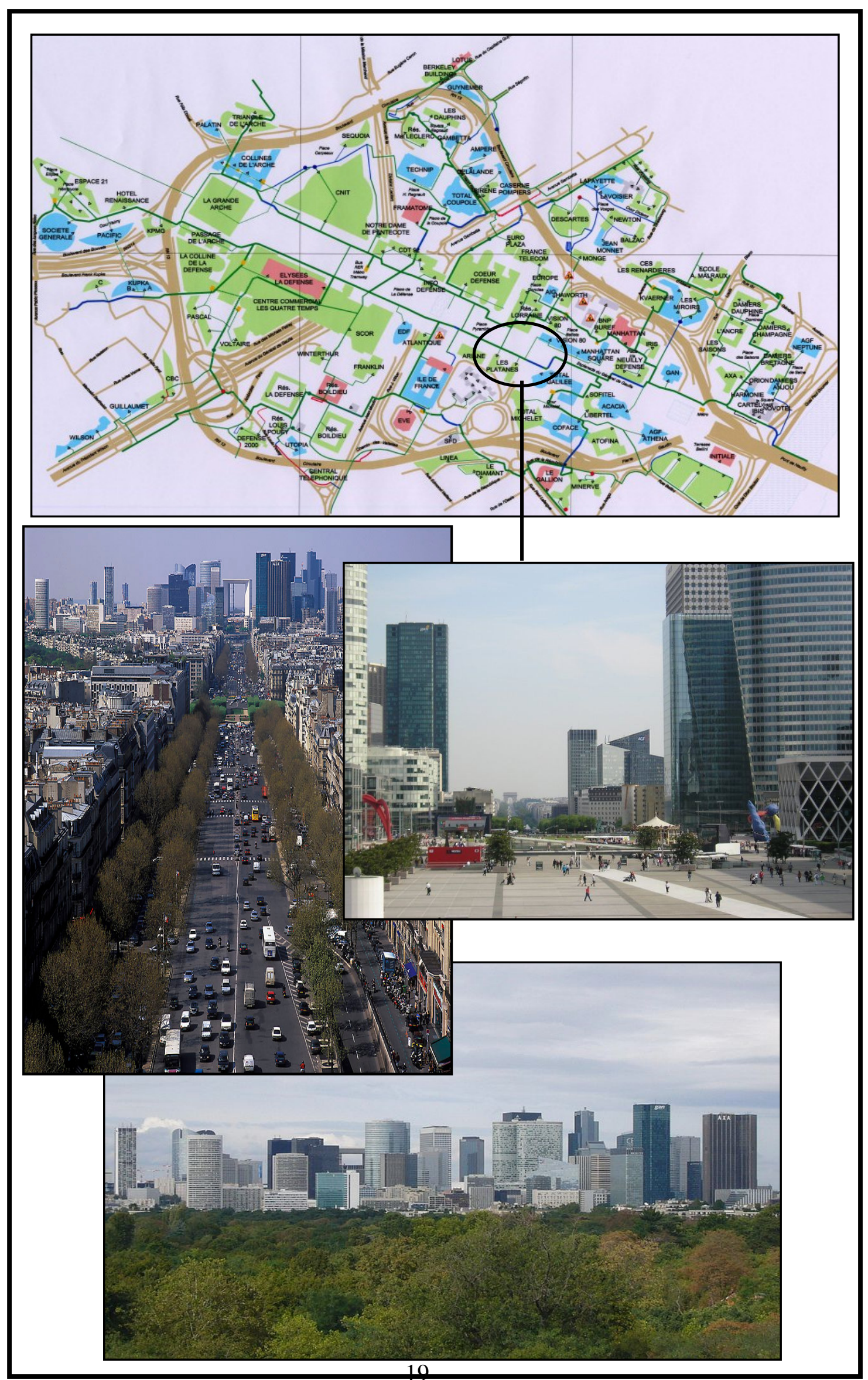

Fuente: Google imágenes. Elaboración propia. 
Resulta entonces oportuno observar la nueva clientela del sector terciario que se ha desarrollado en este eje, ya que para tomar ventaja de la nueva clientela de ejecutivos y empleados los comercios tradicionales están copiando los estilos que están teniendo éxito en el centro de París, es decir, el estilo de boutique para ropa, y el estilo self service para los cafés.

A su vez estamos asistiendo a una nueva ubicación de las oficinas, ya que esos nuevos espacios para oficinas se establecen en ocasiones de manera dispersa, en ocasiones de manera concentrada, influidos por la congelación del mercado inmobiliario en los distritos centrales. Este traslado del centro de la ciudad es en gran medida la consecuencia del gran movimiento de concentración y fusión de empresas. Por lo tanto se habla de un descenso de esta actividad en el CBD tradicional con el surgimiento de un nuevo CBD anexo (la Défense).

La descentralización de oficinas y centros de dirección gracias a las TICs ha provocado una modificación profunda en París. Así, la avenida de Neuilly, por ejemplo, ha acogido grandes centros de datos y gestión en edificios de nueva construcción situados a medio camino entre los Campos Elíseos y las torres del CBD la Défense. Por otro lado, los grandes centros de gestión automatizada han migrado hacia los barrios periféricos y suburbanos, como por ejemplo, el grupo de seguros francés Drouot á Marly-le-Roi (Bastié y Dézert, 1980).

Las exigencias de la concentración económica, el uso de TICs y la situación del mercado inmobiliario va remarcar el divorcio entre la ubicación de las sedes centrales de las empresas y por otro lado el establecimiento de bancos u otros servicios. Todas las principales áreas metropolitanas están teniendo esta descentralización, especialmente París.

Para las grandes empresas, la necesidad de combinar la oficina moderna asociada al centro de toma de decisiones, y las oficinas con una concepción científica a la par que industrial precisan de estas localizaciones periféricas. Así, se ha pasado de un centro de toma de decisiones en los negocios a un cuartel general comercial y de recreación con unos anexos de carácter semi-residencial de lujo.

Sin embargo, para los bancos no hay disociación entre la gestión y ejecución. La gestión de los bancos y los seguros de depósitos sigue comprometida con el centro de la ciudad vieja, debido a la conveniencia de las relaciones de los bancos con la bolsa de valores, los ministerios y los profesionales del asesoramiento. Algunos distritos en los suburbios de París, por ejemplo Reims, se convirtieron en centros de la descentralización de las oficinas ejecutivas de las principales compañías de seguros (ej. Assurances générales de France).

Por lo tanto tras esta reestructuración anteriormente mencionada se observan tres ejes principales en el centro de París (Figura 9). Se trata del eje monumental, el eje político y el eje cultural. Habiendo quedado apartadas las actividades de centro de mando y parcialmente las económicas (al norte la concentración de oficinas aún es muy alta) es un espacio que ha sido ganado para el ciudadano, el cual vertebrado por los Campos Elíseos conforma un auténtico paraíso para el paseo y descanso en el mismo corazón de París. 
Figura 9. Ejes resultantes tras el surgimiento de La Défense, centro de París.

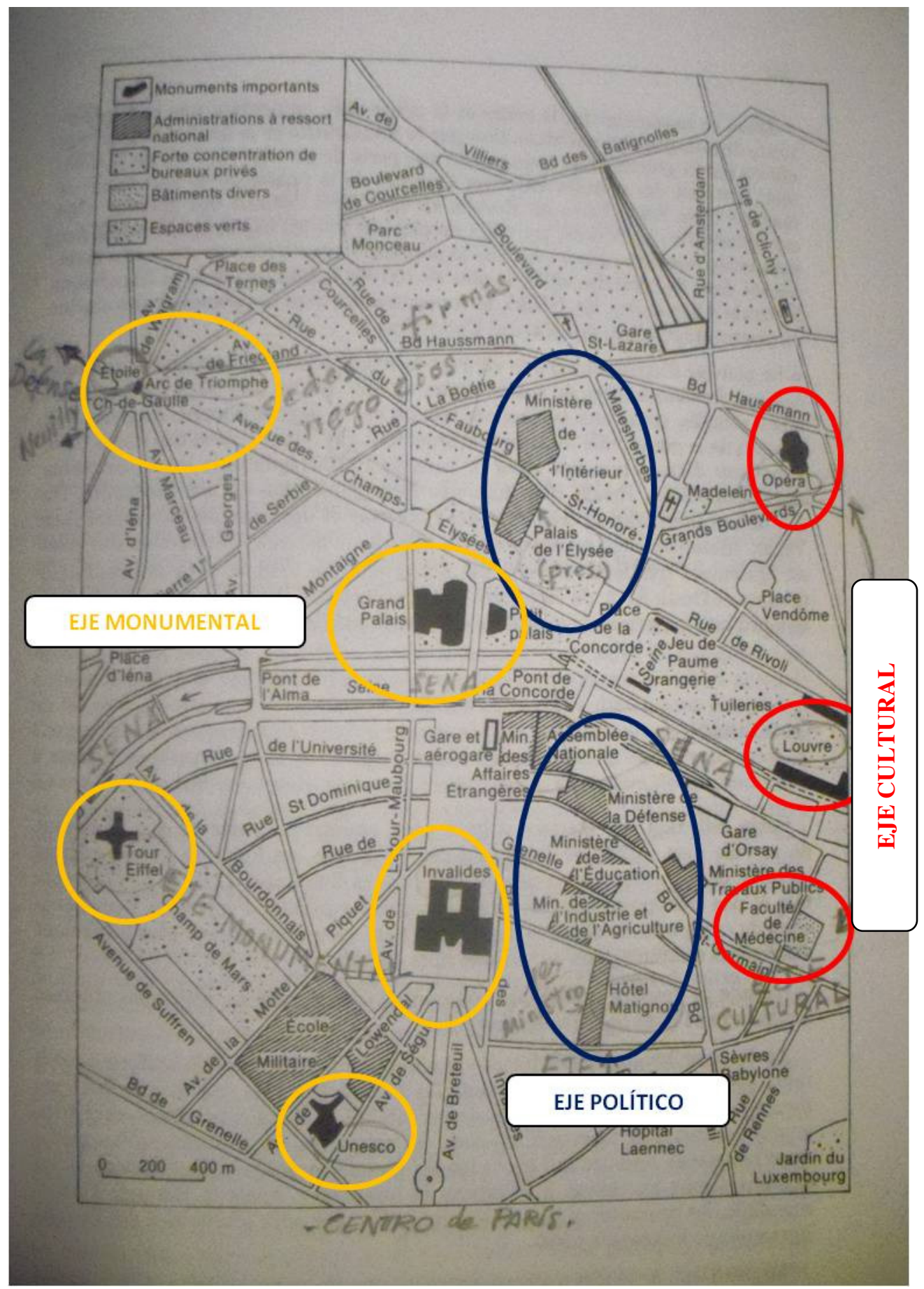

Fuente: J. Bastié y B. Dézert (1980). Elaboración propia.

La existencia en el centro de la ciudad de un importante eje de transporte público refuerza la función de mediación entre el centro de negocios y el centro de consumo, así lo demuestra la evolución del barrio Saint-Lazare en París, con una gran multiplicación de agencias de viajes, agencias de empleo e incluso las agencias matrimoniales. Sus 
clientes suelen acceder a través del metro y del transporte de cercanías, a ellos la congestión del centro no les afecta (Bastié y Dézert, 1980).

En resumen, se localizan en este centro menos oficinas y más actividades comerciales renovadas. Por lo tanto se puede afirmar que las metrópolis ejercen funciones de elevada complejidad: proporcionan economías de aglomeración y proximidad, estimulan la creatividad y la innovación, facilitan la accesibilidad e interacción social, se integran en red con el mundo exterior y alcanzan un máximo bienestar colectivo, desempeñando un papel estratégico en el mundo globalizado ya que son el espacio en el que se localizan las funciones, actividades y servicios que estructuran el sistema económico internacional.

A su vez, se enfrentan a un incremento de los costes económicos, sociales y ambientales asociados a la congestión de las infraestructuras, el alto precio del suelo y la vivienda, junto a una creciente competencia interurbana y la frecuente dificultad de las estructuras del gobierno local para gestionar con eficacia problemas que, a menudo, desbordan sus competencias.

El resultado es el declive de determinadas actividades de larga tradición pero poco competitivas hoy en estas áreas, la deslocalización total o parcial de algunas empresas y la consiguiente reducción en aquellos empleos asociados.

Así, R. Méndez y J. Rodríguez plantean el concepto de metrópolis policéntrica (idea similar a los planteamientos de duplicidad del centro expuestos por Bastié y Dézert) consistente en la aparición de concentraciones secundarias de empresas y empleos en subcentros localizados, sobre todo, a lo largo de las principales vías de circulación y en los nodos intermodales de transporte (con accesibilidad incluso mayor que las áreas centrales) hasta llegar a la construcción de ciudades de borde o edge cities ${ }^{14}$. Frente al anterior proceso de suburbanización residencial, la novedad estriba ahora en la integración de las viviendas con áreas de actividad y empleo, lo que reduce su dependencia respecto a los espacios centrales de la aglomeración ${ }^{15}$ (Méndez y Rodriguez, 2007).

Conviene no olvidar la especial importancia que cobran las zonas verdes en los nuevos usos del CBD. En Europa, con el gran peso que cobran las funciones residenciales y terciarias, este distrito goza de enorme vida durante el día así como durante la noche. El paisaje característico que ofrece se ve muy enriquecido por estos pulmones verdes y por el cauce de los ríos, tanto en el caso de París (Sena) como en el de Londres (Támesis) que hacen de estos ámbitos lugares para el esparcimiento, el paseo o el deporte.

\footnotetext{
${ }^{14}$ Las Edge Cities nacieron en EE.UU. en los 80 y su éxito ha sido tan fulgurante que actualmente dos terceras partes del espacio de oficinas existente en el país se concentra en ellas (Garreau, 1991). La razón que explica este fenómeno es que, en comparación con los centros urbanos, las Edge Cities ofrecen a las empresas muchas ventajas: suelo más barato, seguridad, eficientes comunicaciones terrestres, avanzado equipamiento tecnológico y una elevada calidad de vida para sus empleados y directivos. Éstos encuentran en ellas entornos de alto valor ambiental, espectaculares centros comerciales, fantásticas instalaciones deportivas, selectos clubs de golf o magníficos colegios, todo ello en un entorno plagado de lagos y zonas verdes, bosques, sendas peatonales, carriles bici...

15 Al mezclar residencias y centros de trabajo se convierten en unidades urbanas funcionalmente autónomas, cuyos habitantes escapan a los atascos cotidianos generados por los desplazamientos pendulares casa-oficina.
} 
La ubicación de estas zonas verdes queda bastante repartida a lo largo del CCN (Figura 10) conformando en algunos casos auténticos ejes (Campos Elíseos en París) en contraposición a la compacidad que supone el CBD norteamericano.

\section{Figura 10. Zonas verdes en el CCN de París (superior) y Londres (inferior).}

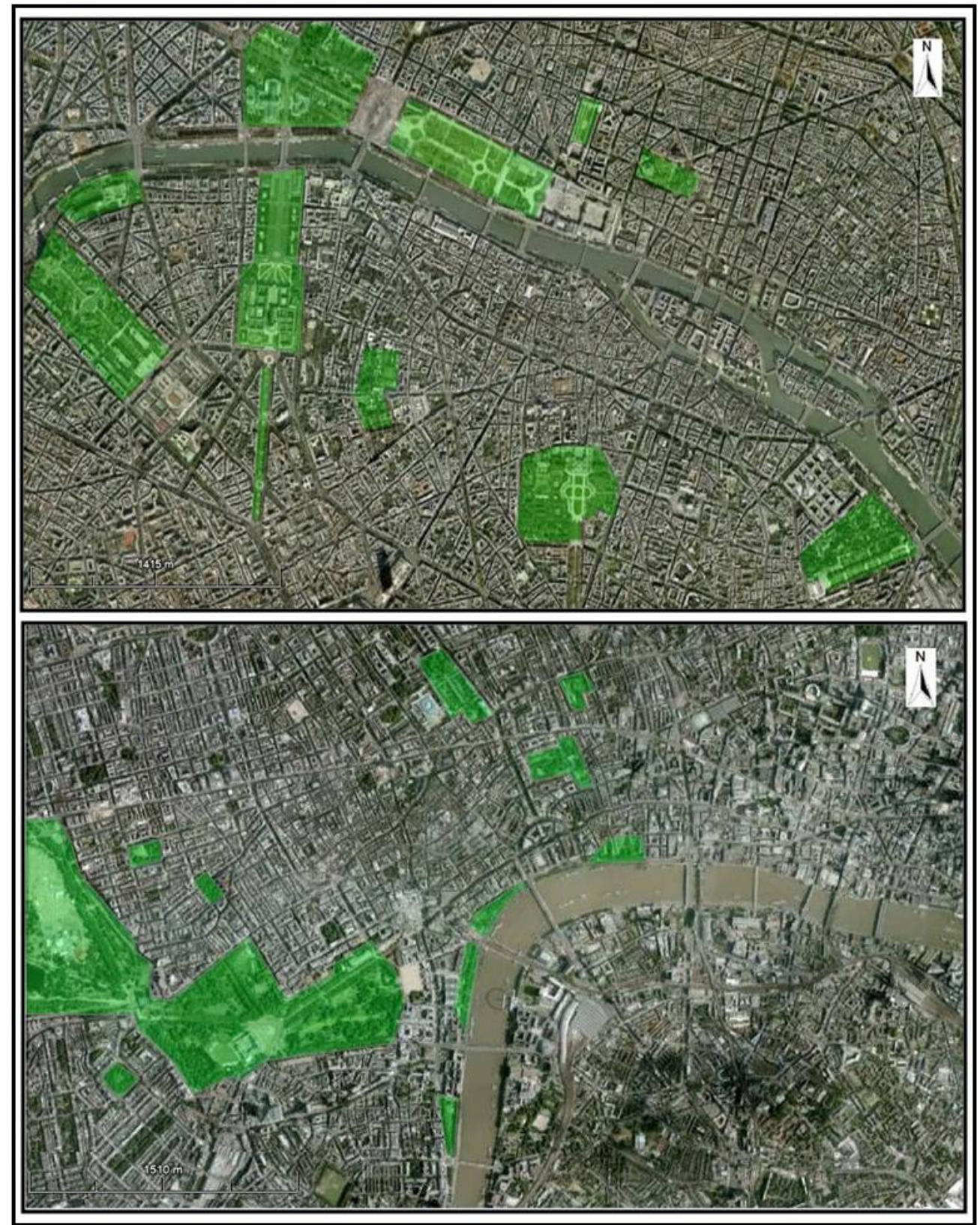

Fuente: Google Earth. Elaboración propia.

Estas zonas verdes son una muestra de la conquista de la calle por parte del ciudadano, que mediante el uso social la hace suya. De esta manera, durante el día se observan actividades financieras junto a actividades comerciales, y en el transcurso de la tarde este área se llena de gente paseando en un abanico tan amplio que abarca desde los mismos directivos o trabajadores de las entidades financieras a los vecinos de los 
residenciales de semi-lujo junto a sus hijos y familiares. Esto se ve reforzado por la mayor actividad comercial que se sucede durante la tarde-noche, estableciéndose una fusión espacial de los conceptos ocio y comercio.

En estos ejemplos no solamente el número de rascacielos es notablemente inferior a los existentes en modelos de CBD norteamericano, sino que no se localizan concentrados en un mismo espacio. Poseen una importancia muy relativa dentro del CCN, a diferencia del CBD norteamericano donde los elementos destacables son esencialmente los propios rascacielos.

De esta manera, diferentes funciones conllevan diferentes expresiones en el espacio por lo que las zonas verdes en el modelo de CBD norteamericano se rigen por otros parámetros. En el caso de Tokio (Figura 11), las zonas verdes no aparecen repartidas por el CBD sino que existe un distrito financiero geográficamente muy concentrado que se manifiesta a través de rascacielos, y no lejos del mismo aparecen auténticos pulmones verdes que contrastan fuertemente con el incesante ajetreo diario de las oficinas del CBD. Ambos se encuentran a escasa distancia, pero están perfectamente delimitados y separados. Las funciones de cada ámbito son claras, lugar de negocios en el caso del CBD o zona para el disfrute y la tranquilidad en las zonas verdes, pero no llegan apenas a entremezclarse. Ocurre de la misma manera en el caso de Nueva York, con el Downtown como zona de negocios y su relativa cercanía a Central Park, inmenso pulmón verde en el corazón de Manhattan.

Este factor, unido a la multiplicidad de usos del CCN europeo frente al CBD norteamericano confiere distinto tamaño a los mismos, por lo que teniendo clara la premisa de la difícil delimitación de ambos modelos, el CCN generalmente es de mayor extensión que el CBD, algo que se aprecia en las figuras 10 y 11.

Figura 11. Zonas verdes en el entorno del CBD de Tokio.

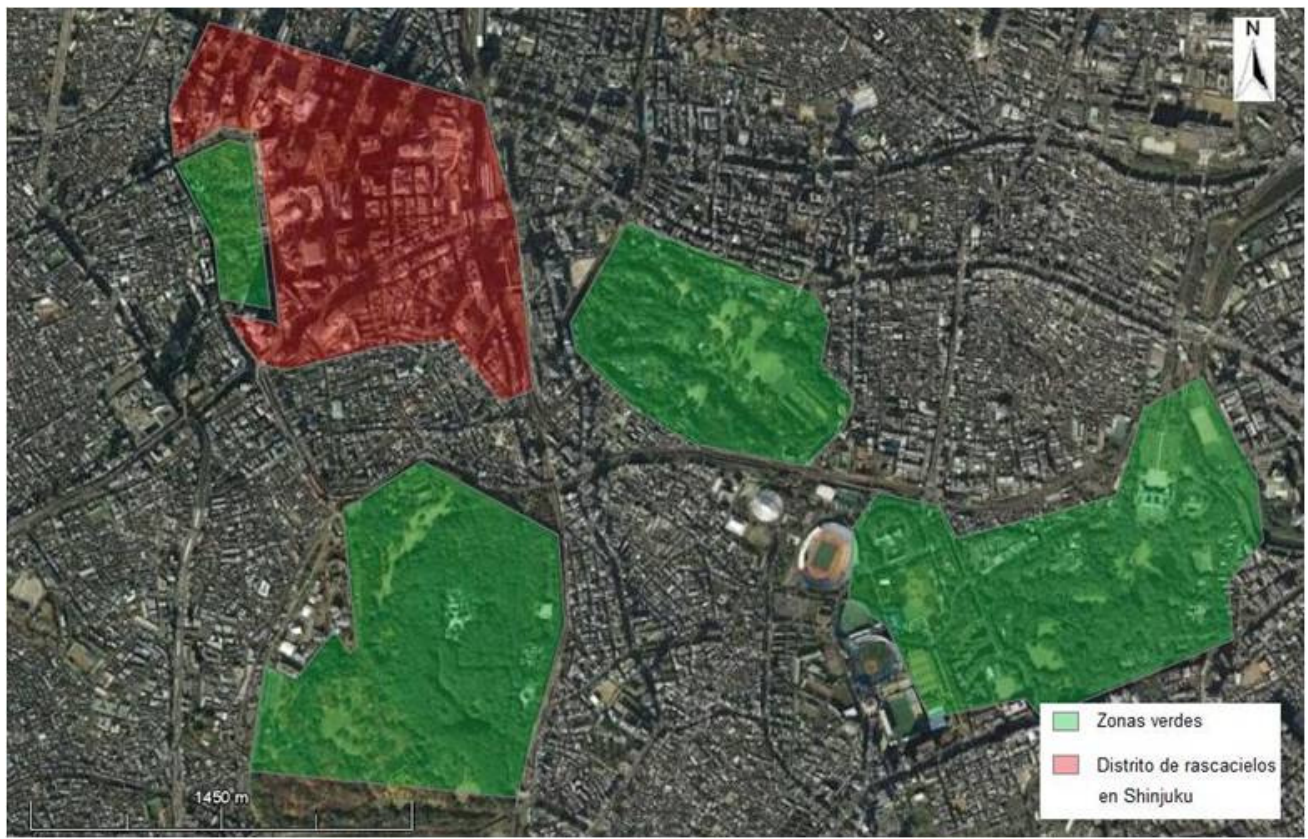

Fuente: Google Earth. Elaboración propia. 


\section{EL CBD EN LOS PAÍSES MENOS DESARROLLADOS}

En los países del Tercer Mundo que han adoptado una economía liberal, abiertos a los mercados extranjeros, los centros de las grandes ciudades también presentan el aspecto de un CBD lo cual refuerza la consideración occidental del mismo. Una vez más, se ven caracterizados por la falta de espacio, así el distrito de negocios se muestra muy congestionado con alta densidad de oficinas, numerosos bancos y diferentes establecimientos comerciales, muy diferenciados de las zonas de comercio locales. Es a menudo producto del distrito administrativo anterior heredado de la época de la colonización europea, este caso se puede distinguir muy claramente en Bombay, Calcuta y especialmente en Nueva Delhi, así como en Singapur y Hong Kong (Bastié y Dézert, 1980).

En el caso de Singapur, su doble presencia histórica ${ }^{16}$ bajo dominio británico (interrumpido únicamente durante la II Guerra Mundial) fue clave para entender su importancia actual. La función que ha ejercido como importantísimo puerto comercial era casi monocultivo hasta la fecha de su independencia, donde se busca una necesaria diversificación sectorial. En la década de los años noventa se produjo su avance importante de las actividades industriales, destacando la electrónica y la petroquímica, sin que ello le haya restado importancia financiera y geopolítica.

Figura 12. CBD de Singapur.

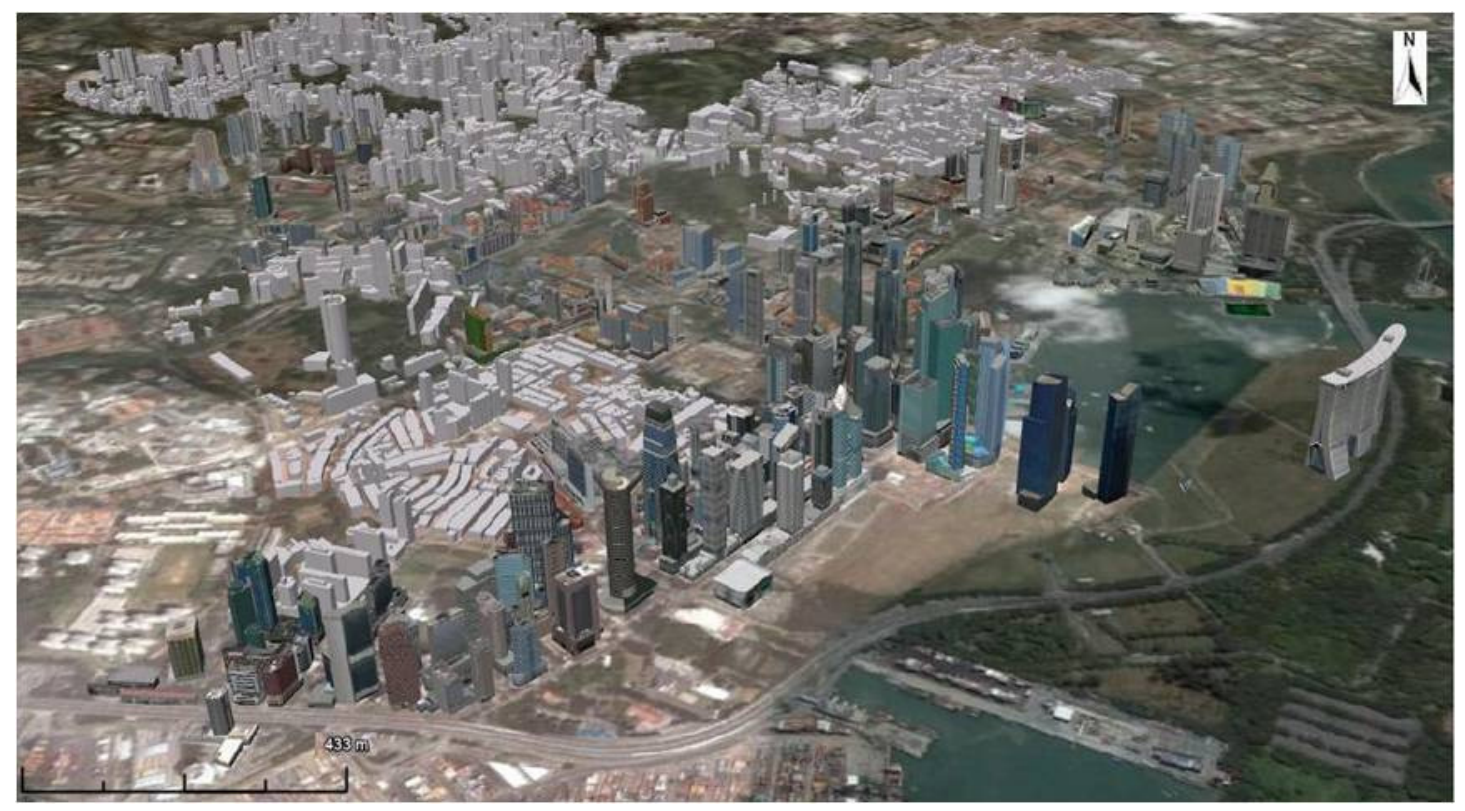

Fuente: Google Earth. Elaboración propia.

${ }^{16}$ El primer mandato británico comienza en 1819 , y es el momento en el cual se puede afirmar que comienza la historia moderna de Singapur, cuando el inglés Thomas Stamford Raffles construye un puerto que permitirá a la isla comerciar con India y China, lo cual llevó a convertirlo en un prestigioso puesto comercial del Sureste Asiático. Sin embago durante la II GM, el Imperio Japonés lo ocupa desde 1942 hasta 1945. Al finalizar la guerra, Singapur vuelve a formar parte de la colonia británica, con altos niveles de autogobierno. Posteriormente en 1963 se une a la Federación de Malasia, pero lo será por muy poco tiempo debido a fuertes diferencias. Finalmente se convertirá en una república independiente en 1965. 
$\mathrm{Su}$ modelo de centro financiero (Figura 12) es de CBD norteamericano. Es eminentemente financiero, no en vano, este sector representa más de una cuarta parte de su PIB. Es la sede del mercado asiático del dólar y cuenta con una activa bolsa de valores, la segunda en importancia de Asia después de la de Tokio.

A pesar de su escaso espacio para construir y lo alto del precio del suelo, las zonas verdes no han sido descuidadas en la planificación, especialmente en el entorno del CBD y el puerto (Figura 13) y marca quizás un ejemplo a seguir donde el explosivo desarrollo económico y el escaso espacio del que se dispone no está reñido con el bienestar ciudadano ${ }^{17}$ y la cuidada ordenación del territorio.

\section{Figura 13. Zonas verdes en el entorno del CBD de Singapur.}

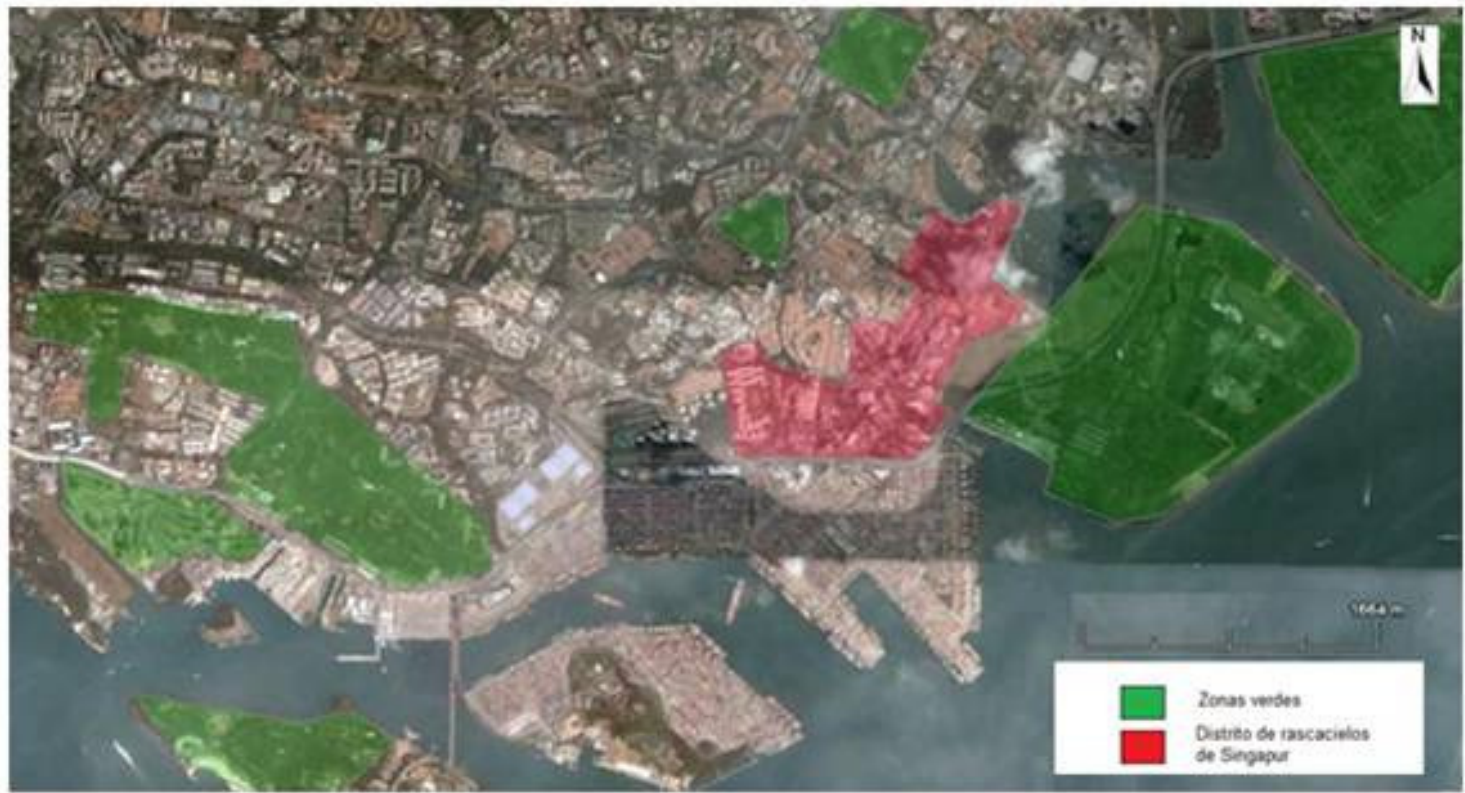

Fuente: Google Earth. Elaboración propia.

En otras ocasiones el CBD de las metrópolis del Tercer Mundo deriva a menudo de la zona europea (por ejemplo, en Casablanca a lo largo de la avenida monumental de Mohamed V) lindando con el centro administrativo, el palacio de gobierno o el palacio real. Las tiendas y oficinas están hacinadas en el centro de la ciudad, mientras que las zonas residenciales son prácticamente nulas en este distrito. Después se pasa bruscamente a una Medina, una ciudad de pequeñas casas y chozas, con sinuosas calles donde hay muchas tiendas de artesanía (Bastié y Dézert, 1980).

\footnotetext{
${ }^{17}$ Singapur posee unas leyes especialmente estrictas que se aplican con rigidez para preservar el orden, la limpieza y la tranquilidad en pro del bienestar ciudadano, y al parecer funcionan dada la extrema limpieza de sus calles pese a poseer una de las mayores tasas de turistas por metro cuadrado del planeta. Es especialmente conocida la prohibición de consumo, fabricación e importación de goma de mascar o la necesidad limpiar un váter público tras haberlo usado bajo la amenaza de abultadas multas.
} 
En estos países el CBD es lo que más fuertemente contrasta con el resto de la ciudad dada la procedencia externa de dicho modelo, con una morfología radicalmente distinta a la original de la ciudad. En muchas ocasiones, el CBD lejos de obtener el significado que representa en las sociedades que le vieron nacer, se desvía hacia la opulencia y la desigualdad.

\section{CONCLUSIONES}

La ciudad es un palimpsesto que puede ser leído e interpretado para describir tanto las sociedades anteriores como la actual. A través de las características que posee se puede caracterizar el modo de vida de sus habitantes, la adaptación al medio, sus costumbres o incluso sus valores o ideología ${ }^{18}$ imperante. Estos factores dejan una impronta en el territorio que se refleja en diferentes concepciones de ciudad, diferentes morfologías, diferentes significados.

Todos estos factores han tenido una importancia variable a lo largo de la historia, y quizás la economía es uno de los que más peso obtiene hoy día. Esto no ha sido siempre así, empero, dicho factor sigue siendo capital para entender el modelado de ciertos espacios donde el factor económico necesariamente debe ocupar puestos más modestos en pro del bienestar común.

Las diferencias entre el modelo norteamericano y el modelo europeo estriban en el desdoblamiento del centro de la ciudad en este último, así se produce una mayor eficiencia donde el centro administrativo y de mando se desvincula del centro de negocios y junto al factor comercial da lugar a un centro de ciudad con mayor actividad comercial, más vivienda y más zonas verdes. Este cambio supone una gran conquista social, sin embargo se ha realizado únicamente por cuestiones económicas ligadas a la especulación inmobiliaria o a la falta de espacio para oficinas en el centro tradicional. Lamentablemente la economía sigue imponiéndose a este efecto reordenando el espacio según sus lógicas, que unas veces juegan a favor del ciudadano, pero que normalmente distan mucho de coincidir.

No obstante esta reordenación también posee sus consecuencias, ya que la búsqueda de esos nuevos centros de ciudad secundarios aprovechando el abundante espacio disponible, o el surgimiento de las Edge Cities a través de enormes vías de comunicación conllevan un voraz consumo de suelo, en zonas periurbanas en las que muchas veces entran en fuerte competencia con usos tradicionales como puede ser la agricultura. De esta manera, y dada la competencia desleal a la que se ven sometidos, los usos tradicionales acaban desapareciendo. A ello hay que sumar la potenciación que este modelo efectúa del uso del vehículo particular, un problema quizás minimizado cuando surgen las Edge Cities. Las consecuencias son la sobrecarga de las infraestructuras existentes, aumento del tráfico y contaminación que conllevan numerosos problemas en estos espacios.

\footnotetext{
${ }^{18}$ Notables ejemplos han constituido durante el s. XX regímenes políticos como el nacionalsocialismo alemán o el sistema soviético que han estado fuertemente ligados a un modelo de ciudad con una arquitectura propia que manifiesta las consignas de dicha ideología.
} 
Los dos modelos de CBD responden a dos concepciones opuestas, lamentablemente en muchas ocasiones al importarlo no se valora qué modelo es más apropiado para cada espacio (ya que utilizar un único modelo que responda a las diferentes realidades espaciales sería igualmente un error) sino que prevalecen otros intereses, como suele ser el económico, que es el que puede acabar rigiendo este y otros espacios. Es una de las grandes amenazas que siempre planea sobre la ordenación del territorio.

\section{BIBLIOGRAFÍA}

BASTIÉ, J. y DÉZERT, B. L'espace urbain. Paris: Masson, 1980.

GARCÍA ESCALONA, E. Una aproximación a la delimitación del CBD de Madrid. Anales de Geografía de la Universidad Complutense, 1987, nº 7, p. 413-420.

GARCÍA ESCALONA, E. Patrimonio, medio ambiente y calidad urbana, las sedes sociales de las empresas. Anales de Geografía de la Universidad Complutense, 1995, $\mathrm{n}^{\circ}$ 15 , p. 325-333.

GARREAU, J. Edge City. Life on the New Frontier. New York: Doubleday, 1991.

MÉNDEZ, R. y RODRÍGUEZ, J. Transformaciones productivas y nuevas formas urbanas: difusión de las actividades económicas en la región metropolitana funcional de Madrid. Anales de Geografía de la Universidad Complutense, 2007, vol. 27, $\mathrm{n}^{\circ}$ 2, p. 105-134.

MORENO, A. y ESCOLANO, S. El comercio y los servicios para la producción y el consumo. Madrid: Síntesis, 1992.

MORENO, A. y ESCOLANO, S. Los servicios y el territorio. Madrid: Síntesis, 1992.

MURPHY, R. y VANCE, J. A comparative study of Nine Central Business Districts. Economic Geography, 1954, n 30, p. 301-336.

WILLIAM-OLSSON, W. Stockholm: Its structure and development. Geographical Review, 1940, n 30, p. 420-438.

\section{Ge Graphos}

